\title{
PENINGKATAN PENGETAHUAN DAN MOTIVASI IBU TENTANG PEMBERIAN ASI EKSKLUSIF
}

\author{
Nurbaiti \\ Program Studi D III kebidanan Sekolah Tinggi Ilmu Kesehatan Baiturrahim Jambi \\ Email korespondensi : nbaiti812@gmail.com
}

\begin{abstract}
Mother's Milk (ASI) is a dynamic liquid that has a variety of nutrients and is complete. The important thing about ASI is that all its contents are in accordance with the baby's condition and are naturally non-synthetic so that they are safe and can be maximally beneficial. This community service activity will be held in the Lebak Pustu Working Area, Bandung. The service method uses a survey, lecture, discussion, demonstration / simulation approach. Problems faced by partners Lack of health knowledge about exclusive breastfeeding the solution is to provide information about health, especially about giving exclusive breastfeeding and hopefully breastfeeding mothers can provide exclusive breastfeeding to their babies The community service team provides a focus on community service in collaboration with Lebak Pustu Bandung officers.
\end{abstract}

Keywords: Exclusive breastfeeding, breastfeeding mothers

\begin{abstract}
ABSTRAK
Air Susu Ibu (ASI) merupakan cairan hidup yang dinamis dan memiliki kandungan gizi beragam maupun lengkap. Hal penting mengenai ASI bahwa segala kandungannya sesuai keadaan bayi dan bersifat alami bukan sintetik sehingga aman dan dapat bermanfaat secara maksimal. Kegiatan Pengabdian masyarakat ini akan dilaksanakan di Wilayah Kerja Pustu Lebak Bandung. Waktu pelaksanaan pengabdian kepada masyarakat ini pada tanggal 25 s/d 27 Juli 2017, di kelurahan Lebak Bandung dengan sasaran ibu-ibu yang menyusui Metode pengabdian menggunakan pendekatan survei, ceramah, diskusi, demonstrasi/simulasi. Permasalahan yang dihadapi mitra Kurangnya Pengetahuan kesehatan tentang ASI Eksklusif solusinya memberikan informasi tentang kesehatan khususnya tentang Pemberian ASI Eksklusif dan di harap kan ibu - ibu menyusui dapat memberikan ASI Eksklusif pada bayinya Tim pengabdian masyarakat memberikan fokus pengabdian masyarakat bekerja sama dengan petugas Pustu Lebak Bandung. Hasil dari pengabdian kepada masyarakat di Lebak Bandung Kota Jambi, ibu-ibu menyusui mengerti tentang ASI eksklusif, manfaat ASI untuk bayi serta mengetahui langkah keberhasilan dalam pemberian ASI eksklusif dan termotivasi untuk memberikan ASI Eksklusif pada bayinya.
\end{abstract}

Kata Kunci: ASI Eksklusif, Ibu-ibu Menyusui

\section{PENDAHULUAN}

Salah satu indikator yang menunjukkan kualitas suatu bangsa adalah terpeliharanya derajat kesehatan keluarga sejak dini, ditunjukkan dengan umur harapan hidup waktu lahir, Angka Kematian Bayi (AKB), Angka Kematian Balita (AKABA), Angka Kematian Ibu (AKI) dan Angka Kematian
Kasar (Kemenkes RI, 2013). Berdasarkan data yang didapat dari Profil Kesehatan Indonesia menunjukkan bahwa berdasarkan hasil Survei Penduduk Antar Sensus (SUPAS) tahun 2015 menunjukkan AKB sebesar 22,23 per 1.000 kelahiran hidup dan AKABA sebesar 26,29 per 1.000 kelahiran hidup (Kemenkes RI, 2016). 
Data dari Profil Kesehatan Provinsi Jambi menunjukkan bahwa pada tahun 2015 jumlah kematian bayi (AKB) sebanyak 201 kasus. Dari Kabupaten Provinsi Jambi angka tertinggi kematian bayi di Kabupaten Merangin sebanyak 37 $(18,4 \%)$ dan di Kota Jambi angka kematian bayi sebanyak 19 (9,4\%) (Dinkes Provinsi Jambi, 2016).

Berdasarkan penelitian Story dan Parish 2011 tentang ASI eksklusif menunjukkan bahwa kematian bayi dapat diturunkan dengan pemberian ASI eksklusif. Hasil menyatakan bahwa secara signifikan ASI menurunkan insiden diare dan infeksi saluran pernafasan. Didukung oleh penelitian Arifeen tahun 2011 yang menunjukkan bahwa pemberian ASI eksklusif pada beberapa bulan pertama dapat menurunkan risiko kematian akibat diare sebesar 3,9 kali dan kematian akibat Infeksi Saluran Pernafasan Akut (ISPA) sebesar 2,4 kali (Haryono dan Sulis, 2014).

Air Susu Ibu (ASI) merupakan cairan hidup yang dinamis dan memiliki kandungan gizi beragam maupun lengkap. Hal penting mengenai ASI bahwa segala kandungannya sesuai keadaan bayi dan bersifat alami bukan sintetik sehingga aman dan dapat bermanfaat secara maksimal (Werdayanti, 2015).

World Health Organization (WHO) telah merekomendasikan untuk menyusui secara eksklusif dalam 6 bulan pertama kehidupan bayi dan melanjutkannya untuk waktu dua tahun atau lebih, karena ASI sangat seimbang dalam memenuhi kebutuhan nutrisi bayi yang baru lahir dan merupakan satu-satunya makanan yang dibutuhkan sampai usia enam bulan (Pollard, 2016). Pada Tahun 2004 melalui Kepmenkes RI No. 450/Menkes/SK/IV dengan menetapkan target pemberian ASI eksklusif 6 bulan sebesar 80\% (Fikawati, dkk, 2015). Kebijakan ini berdasarkan hasil penelitian yang mengemukakan bahwa pemberian makanan atau minuman pendamping ASI malah akan menyebabkan pengurangan kapasitas lambung bayi dalam menampung asupan cairan ASI sehingga pemenuhan ASI yang seharusnya dapat maksimal telah tergantikan oleh makanan pendamping (Jannah, 2011).

Organisasi dunia WHO telah mengkaji atas lebih dari 3.000 penelitian menunjukkan pemberian ASI selama 6 bulan adalah jangka waktu yang paling optimal untuk pemberian ASI eksklusif (Haryono dan Sulis, 2014). ASI merupakan makanan yang terbaik bagi bayi pada 6 bulan pertama kehidupannya. Semua kebutuhan nutrisi yaitu protein, karbohidrat, lemak, vitamin dan mineral sudah tercukupi dari ASI (Fikawati, dkk, 2015). Komposisi ASI sampai dengan 6 bulan sudah cukup untuk memenuhi kebutuhan gizi bayi meskipun tanpa tambahan makanan atau minuman pendamping ASI (Jannah, 2011).

ASI mampu memberikan perlindungan bagi bayi, baik perlindungan secara aktif maupun pasif. ASI juga mengandung zat anti infeksi bayi akan terlindung dari berbagai macam infeksi, baik yang disebabkan bakteri, virus, jamur atau parasit. Pemberian ASI sangat dianjurkan, terlebih pada saat empat bulan pertama tetapi bila memungkinkan sampai enam bulan yang dilanjutkan sampai usia 2 tahun dengan makanan padat (Ambarwati dan Diah, 2009).

Asi mengandung zat antibodi yang berperan sebagai sistem pertahanan dinding pencernan terhadap infeksi. Telah dibuktikan bahwa bayi yang mendapat ASI ekslusif mempunyai kadar antibodi yang lebih tinggi dibandingkan dengan yang mendapatkan susu formula. Oleh karena itu, daya tahan tubuh terhadap infeksi bakteri patogen pada bayi dengan ASI lebih besar dibandingkan dengan bayi dengan susu formula

Berdasarkan data yang diperoleh dari Dinas Kesehatan Kota Jambi mengenai pencapaian ASI eksklusif tahun 2015 dan tahun 2016 didapat bahwa jumlah cakupan pemberian ASI eksklusif di Kota Jambi 
tahun 2015 sebesar $3.322(67,8 \%)$ dan tahun 2016 sebesar $2.168(63,97 \%)$. Jumlah cakupan ASI eksklusif di Kota Jambi masih tergolong rendah karena tidak sesuai dengan target pemerintah yang menetapkan pemberian ASI eksklusif dengan target $80 \%$.

ASI eksklusif adalah pemberian ASI tanpa makanan dan minuman pendamping (termasuk air jeruk, madu, air gula), yang dimulai sejak bayi baru lahir man sampai dengan usia 6 bulan (Sulistiyawati, 2009). Menurut WHO ASI eksklusif adalah pemberian ASI saja pada bayi sampai usia 6 bulan tanpa tambahan cairan ataupun makanan lain. ASI dapat diberikan sampai bayi berusia 2 tahun (Yanti, 2011).

Menurut Widuri (2013), Suatu pemberian ASI dari ibunya terhadap bayinya yang mana bayi hanya diberikan ASI saja tanpa minuman atau makanan lainnya temasuk air putih maupun vitamin lainnya. Pemberian ASI eksklusif dianjurkan untuk jangka waktu minimal empat bulan dan akan lebih baik lagi apabila diberikan sampai bayi berusia enam bulan.

WHO

dan

UNICEF

merekomendasikan kepada para ibu, bila memungkinkan memberikan ASI esklusif sampai 6 bulan dengan menerapkan (Yanti, 2011) :1). Inisiasi menyusui dini selama 1 jam setelah kelahiran bayi.2). ASI eksklusif diberikan kepada bayi hanya ASI saja tanpa makanan tambahan atau minuman.3). ASI diberikan secara on demand atau sesuai kebutuhan bayi, setiap hari setiap malam.4). ASI diberikan tidak menggunakan botol, cangkir maupun dot.

Manfaat ASI bagi bayi yaitu Pemberian ASI merupakan metode pemberian makan bayi yang terbaik, terutama pada bayi umur kurang dari 6 bulan. selain juga bermanfaat bagi ibu. ASI mengandung semua zat gizi dan cairan yang dibutuhkan untuk memenuhi seluruh gizi bayi pada 6 bulan pertama kehidupannya. Pada umur 6 sampai 12 bulan, ASI masih merupakan makanan utama bayi, karena mengandung lebih dari $60 \%$ kebutuhan bayi. Guna memenuhi semua kebutuhan bayi, perlu ditambah dengan Makanan Pendamping ASI (MP-ASI). Setelah umur 1 tahun, meskipun ASI hanya bisa memenuhi 30\% dari kebutuhan bayi, akan tetapi pemberian ASI tetap dianjurkan karena masih memberikan manfaat.

Manfaat bagi ibu di antaranya adalah mengurangi perdarahan setelah persalinan, mempercepat pemulihan kesehatan ibu, menunda kehamilan berikutnya dan mengurangi resiko terkena kanker payudara, (Depkes,2001). Ditinjau dari aspek ekonomi, dengan menyusui secara eksklusif, ibu tidak perlu mengeluarkan biaya untuk makanan bayi sampai bayi berumur 6 bulan.Dengan demikian akan menghemat pengeluaran rumah tangga untuk membeli susu formula dan peralatannya.

Manfaat bagi keluarga ekonomis, dan lebih praktis, bermanfaat juga bagi Negara menurunkan angka kesakitan dan kematian bayi, menghemat devisa Negara, mengurangi subsidi ruah sakit dan peningkatan kualitas generasi penerus.

Menurut Jannah (2011), langkah keberhasilan ASI eksklusif adalah Persiapkan payudara bila diperlukan, mempelajari ASI dan tatalaksana menyusui, menciptakan dukungan keluarga, teman, dan lingkungan, memilih rumah sakit asuhan sayang bayi, memilih tenaga kesehatan yang mendukung pemberian ASI eksklusif, mendatangi fasilitas konsultasi laktasi untuk persiapan apabila ibu menemui kesulitan saat menyusui, menciptakan sikap yang positif tentang ASI dan menyusui.

Masalah yang di hadapi mitra adalah Kurangnya Pengetahuan kesehatan tentang ASI Eksklusif dan memberikan informasi tentang kesehatan khususnya tentang Pemberian ASI Eksklusif. Tujuan dalam melakukan pengabmas ini untuk meningkatkan pengetahuan dan memotivasi 
ibu - ibu tentang pemberian ASI Ekslusif dan di harapkan ibu - ibu menyusui dapat memberikan ASI Eksklusif pada bayinya. Oleh karena itu tim pengabdian berupaya melakukan penyuluhan pada ibu.

\section{TARGET DAN LUARAN}

Target dan luaran Tim Pengabdian masyarakat berupaya agar para ibu menyusui memproleh pengetahuan tentang ASI eksklusif dan termotivasi untuk memberikan ASI secara eksklusif pada bayinya.

\section{METODE PELAKSANAAN}

Waktu pelaksanaan pengabdian kepada masyarakat ini pada tanggal $25 \mathrm{~s} / \mathrm{d}$ 27 Juli 2017, di Lebak Bandung dengan sasaran ibu-ibu yang menyusui. Adapun metode kegiatan meliputi penyuluhan, ceramah dan Tanya jawab, media yang digunakan leaflet, LCD dan leptop.

\section{HASIL DAN PEMBAHASAN}

Hasil dari pengabdian kepada masyarakat di Lebak Bandung Kota Jambi, ibu-ibu menyusui mengerti tentang ASI eksklusif, manfaat ASI untuk bayi serta mengetahui langkah keberhasilan dalam pemberian ASI eksklusif dan termotivasi untuk memberikan ASI Eksklusif pada bayinya.

ASI mampu memberikan perlindungan bagi bayi, baik perlindungan secara aktif maupun pasif. ASI juga mengandung zat anti infeksi bayi akan terlindung dari berbagai macam infeksi, baik yang disebabkan bakteri, virus, jamur atau parasit. Pemberian ASI sangat dianjurkan, terlebih pada saat empat bulan pertama tetapi bila memungkinkan sampai enam bulan yang dilanjutkan sampai usia 2 tahun dengan makanan padat.

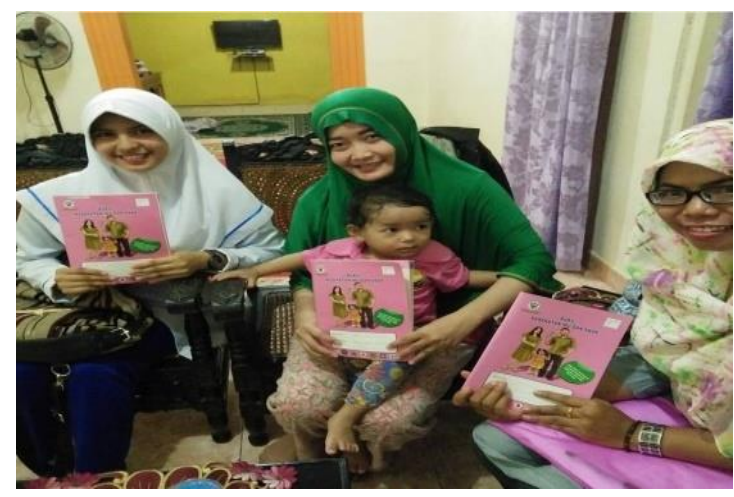

Gambar I. Pemberian pendidikan kesehatan kepada ibu menyusui

\section{KESIMPULAN DAN SARAN}

\section{Kesimpulan}

Pelaksanaan pengabdian kepada masyarakat yang dilakukan untuk peningkatan pengetahuan dan motivasi ibu dalam pemberian asi eksklusif, dan diharapkan agar ibu-ibu dapat memberikan ASI eksklusf pada bayinya selama 6 bulan.

\section{Saran}

Kepada Instansi yang terkait disarankan agar melakukan kegiatan penyuluhan secara rutin sehingga ibu ibu termotivasi untuk memberikan ASI eksklusif pada anaknya.

\section{UCAPAN TERIMAKASIH}

Tim Pengabdian kepada Masyarakat mengucapkan terimakasih yang sebesarbesarnya kepada STIKes Baiturrahim Jambi atas dana dan fasilitas serta izin dalam melakukan pengabdian masyarakat ini dan juga kepada masyarakat lebak bandung khususnya lurah, RT dan ibu-ibu yang telah memberikan izin tempat melakukan pengabdian masyarakat ini sehingga kegiatan ini berjalan dengan lancar. 


\section{DAFTAR PUSTAKA}

Haryono, R., Sulis, S. (2014). Manfaat ASI Eksklusif. Yogyakarta: Gosyen Publishing.

Jannah, N. (2011). Asuhan Kebidanan Masa Nifas. Jogjakarta: Penerbit ArRuz Media.

Kemenkes RI. (2013). Riset Kesehatan Dasar Tahun 2013. Jakarta.. (2016). Profil Kesehtaan Indonesia Tahun 2015. Jakarta.

Listyaningrum. (2016). Tingkat Pengetahuan dan Motivasi Ibu Berhubungan dengan PemberianASI Eksklusif pada Ibu Bekerja. S1 Ilmu Keperawatan FIKES UNRIYO, Yogyakarta.

Nurjanah, S. (2013). Asuhan Kebidanan Post Partum. Bandung: Refika Aditama.

Pollard, M. (2015). ASI Asuhan Berbasis Bukti. Jakarta: EGC.

Rondonuwu (2014). Tingkat Pengetahuan Ibu Menyusui Tentang Pemberian ASI Eksklusif di Bagian Obstetri dan Ginekologi Blu RSU Prof. Dr. R. D. Kandou manado. Skripsi. Fakultas Kedokteran Universitas Sam Ratulangi, Manado.

Yanti, Damai, 2011. Asuhan Kebidanan Masa Nifas. Refika Aditama. Bandung.

Werdayanti, R. (2015). Welcome to the Exclusive Club ASI Eksklusif. Yogyakarta: Familia.

Wiji, R. (2013). ASI dan Panduan Ibu Menyusui. Yogyakarta: Yogyakarta.
Yanti, D. (2011). Asuhan Kebidanan Masa Nifas. Bandung: Refika Aditama. 